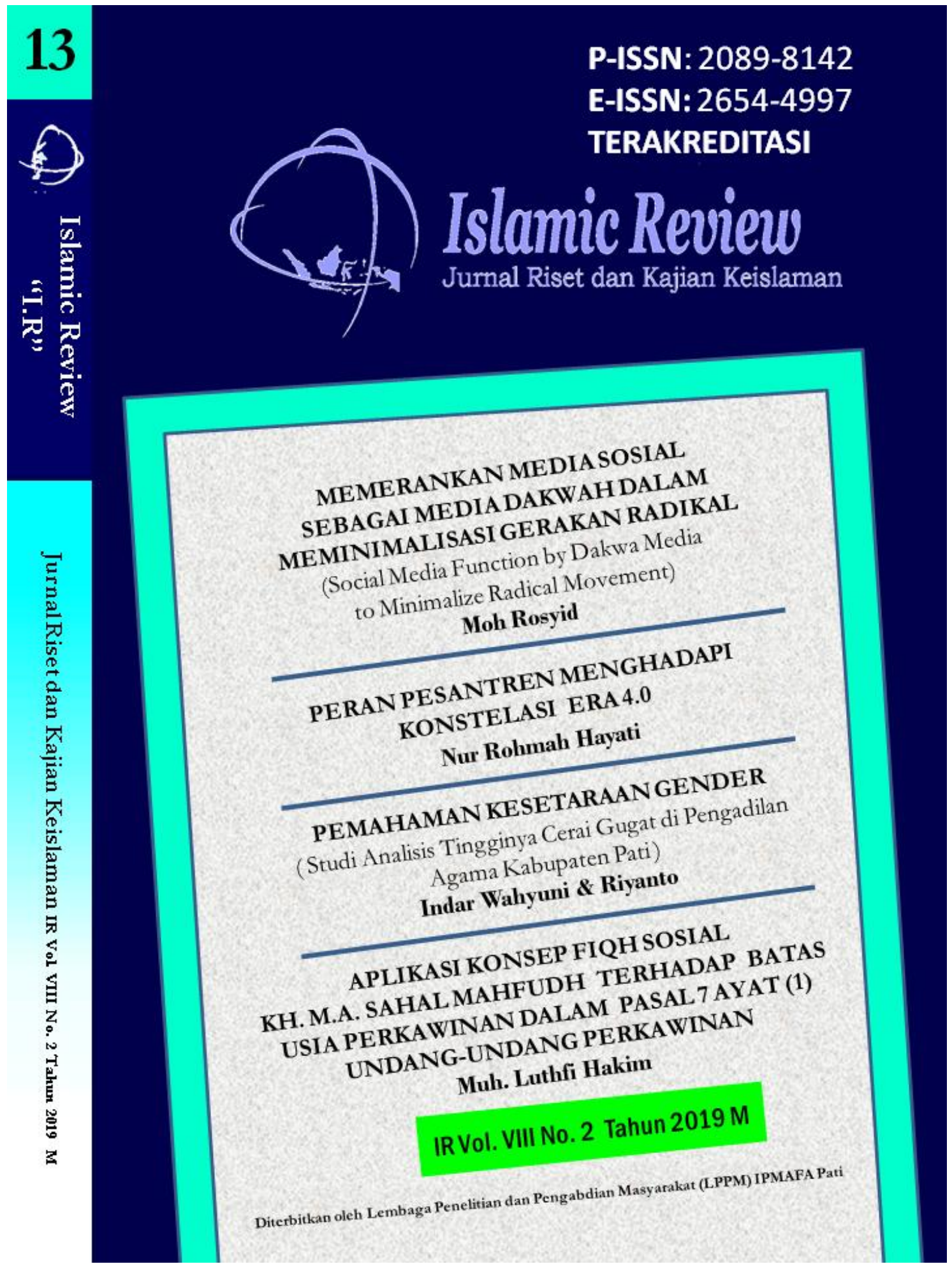


P-ISSN: 2089-8142

E-ISSN: 2654-4997

TERAKREDITASI

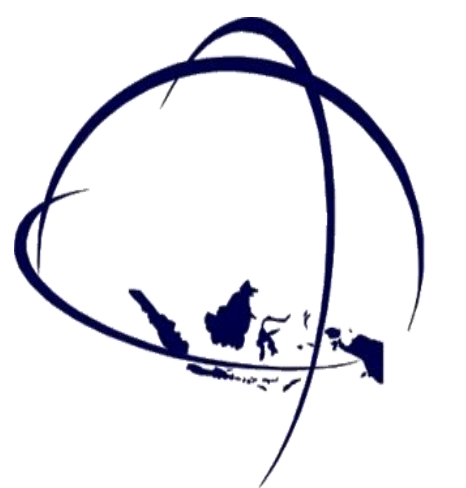

Islamic Review Jurnal Riset dan Kajian Keislaman

IPMAFA PRESS 


\section{Susunan Redaksi \\ ISLAMIC REVIEW}

'IR'

Jurnal Riset dan Kajian Keislaman

Intitut Pesantren Mathali'ul Falah (IPMAFA)

Pati, Jawa Tengah

\section{Penanggungjawab}

Abdul Ghaffar Rozin (Rektor IPMAFA Pati)

\section{Editorial Board}

Syamsul Ma'arif, (Scopus ID 57196279085) Universitas Islam Negeri Walisongo, Semarang Khoirun Niam, (Scopus ID: 57200652037; h-index: 1) Universitas Islam Negeri (UIN) Sunan Ampel, Surabaya Moch Nur Ichwan, (Scopus ID: 39361628400; h-index: 2) Sunan Kalijaga State Islamic University, Yogyakarta

Al makin, (Scopus Author ID: 38162109000, h-index: 2) Sunan Kalijaga State Islamic University, Yogyakarta

Andar Nubowo, Nahyang Technological University, Singapore

Muhammad Syafiq, Nahyang Technological University, Singapore

Muhyar Fanani, Universitas Islam Negeri Walisongo, Semarang

Dimyati, Institut Pesantren Mathali'ul Falah Pati

Agus Waluyo, Institut Agama Islam Negeri Salatiga

Nur Said, Institut Agama Islam Negeri Kudus

\section{Editorial Team}

Editor In-Chief

Managing Editor

Editor

Asisten Editor

: A. Zaenurrosyid, Institut Pesantren Mathali'ul Falah Pati

: M. Sofyan Al-Nashr, Institut Pesantren Mathali'ul Falah Pati

: Isyrokh Fuadi, Institut Pesantren Mathali'ul Falah Pati

: Nur Khoiriyah, Institut Pesantren Mathali'ul Falah Pati

: Ahmad Dalhar Maarif, Institut Pesantren Mathali'ul Falah Pati

\section{Penerbit}

: Arina Ulfatul Jannah, Institut Pesantren Mathali'ul Falah Pati

IPMAFA Press

Frekuensi terbit 2 kali setiap 6 bulan sekali (April dan Oktober)

\section{ALAMAT REDAKSI}

Lantai 1 Kampus IPMAFA, Jl. Raya Pati-Tayu KM 20, Purworejo Margoyoso Pati Jawa Tengah 59154, Telp.: 0295-5501999, Hp: 085743602 083, Fax: 0295-4150081, Website: http://journal.ipmafa.ac.id/, Email: islamicreview@ipmafa.ac.id

Redaksi mengundang para pembaca agar berpartisipasi aktif untuk memberikan kontribusi artikel baik hasil pemikiran, penelitian maupun book review pada edisi selanjutnya. Dengan demikian silaturahmi pemikiran akan tetap berlangsung. 
DAFTAR ISI

MEMERANKAN MEDIA SOSIAL SEBAGAI MEDIA DAKWAH DALAM MEMINIMALISASI GERAKAN RADIKAL (Social Media Function by Dakwa Media to Minimalize Radical Movement)

Mob Rosyid. $135-160$

PERAN PESANTREN MENGHADAPI KONSTELASI ERA 4.0

Nur Rohmah Hayati. $161-174$

PEMAHAMAN KESETARAAN GENDER ( Studi Analisis Tingginya Cerai Gugat Di Pengadilan Agama Kabupaten Pati )

Indar Wabyuni \& Riyanto. $175-206$

APLIKASI KONSEP FIQH SOSIAL KH. M.A. SAHAL MAHFUDH TERHADAP BATAS USIA PERKAWINAN DALAM PASAL 7 AYAT (1) UNDANG-UNDANG PERKAWINAN

Muh. Luthfi Hakim. $207-234$

KONSEP MASHLAHAH AL-AMMAH DALAM PERSPEKTIF FIQH SOSIAL KH. MA. SAHAL MAHFUDH

Zahrotun Nafisab \& Arif Chasanuddin $235-258$

تقويم تعليم اللغة العربية (دراسة الاختبرات اللفوية)

Nibayatus Sa'diyah, Risalatul Muawanah, Zakiyah Isnawati. $259-276$

BOOK REVIEW: MENGEKANG EMOSI NEGATIF KUNCI MERAIH KEDAMAIAN DALAM HIDUP

Ab Dalhar Muarif $277-281$ 


\title{
APLIKASI KONSEP FIQH SOSIAL KH. M.A. SAHAL MAHFUDH TERHADAP BATAS USIA PERKAWINAN DALAM PASAL 7 AYAT (1) UNDANG-UNDANG PERKAWINAN
}

\author{
Muh. Luthfi Hakim \\ Dosen Institut Pesantren Mathali'ul Falah Pati \\ Email: luthfistudy@gmail.com
}

\begin{abstract}
The limitation age of marriage in article 7 verse (1) of Law Number 1/1974 on marriage, is considered to cause various problems. The limitation age for marriage of 19 for males and 16 years for females is too early and it is less appropriate with biological, psychological, educational, and economic maturity. Psychologically, marriages under 21 years of age do not yet have maturity. From the aspect of the fulfillment of economic needs, a busband is still not stable to meet family needs. The purpose of this research is to analyze the limitation age of marriage in Law Number 1/1974 by using perspective madzhab qauli fiqh sosial KH . MA. Sabal Mabfudh and analyze the minimum age of marriage in Law Number 1/1974 by using perspective manhaji figh sosial KH. MA. Sahal Mahfudh. The results of this research indicate that: First, the madrhab qauli of figh sosial sees the limitation age of marriage is too low and not in accordance with the condition that exist in society, and it will cause to adverse impacts. Therefore the preventive effort has to be done, it is in accordance with the rules of figh ad-daf'u aqwa min ar-raf'i. Secondly, the madrhab manhaji of figh sosial through the the theory of masalikul illat say that the limitation age of marriage in Law Number 1/1974 must be integrated with the purpose of marriage and create al-maslahah al-'ámmah.
\end{abstract}

Keywords: The limitation age of marriage, Law Number 1/1974, Figh Sosial.

\footnotetext{
Abstrak

Pembatasan usia perkawinan di Indonesia secara tegas diatur dalam pasal 7 ayat (1) Undang-Undang Nomor 1/1974. Adanya peraturan tersebut memiliki dampak signifikan dalam meminimalisir praktik perkawinan dini. Hanya saja pada saat ini, pembatasan usia tersebut dinilai terlalu rendah dan kurang sesuai dengan perkembangan calon mempelai, baik perkembangan biologis, psikologis, pendidikan, maupun ekonomi. Penelitian ini dimaksudkan untuk menganalisa batas usia perkawinan dalam

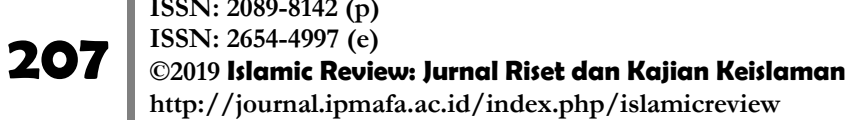


Undang-Undang Nomor 1/1974 perspektif mad₹hab qauli dan mad乏hab manhaji fiqh sosial KH. MA. Sabal Mahfudh. Dalam kajian fiqh klasik memang tidak ada pembatasan usia perkawinan kecuali hanya sebatas persyaratan baligh. Akan tetapi menurut pengembangan madzhab qauli fiqh sosial bahwa baligh harus dimaknai secara kontekstual agar selalu relevan digunakan. Usia 19 dan 16 tahun sebagai batas usia perkawinan di Indonesia jika dikaitkan dengan perubahan kondisi sosial di masyarakat jelas akan melabirkan ekeses-ekses negatif. Maka upaya pencegaban terhadap labirnya halhal negatif harus diupayakan sesuai kaidah figh, "Ad-daf'u aqwā min ar-rafi," bahwa upaya pencegahan terhadap labirny madarat harus dilakukan dibanding dengan menyelesaikan madarat yang labir kemudian. Di samping itu, madřhab manhaji figh sosial memandang batas usia perkawinan di Indonesia sebagai refleski dari makna baligh dan al-bä'ah harus diiterintegrasikan dan menjadi sarana (wasilah) untuk. mecapai tujuan perkawinan serta bermuara pada kemaslahatan umum.

Kata Kunci: Batas Usia Perkawinan, Undang-Undang Nomor 1/1974, Fiqh Sosial.

\section{A. Pendahuluan}

Pemenuhan kebutuhan biologis tidak menjadi satu-satunya tujuan atas pensyari'atan ikatan perkawinan, meskipun hanya dengan cara tersebut penyaluran kebutuhan biologis dibenarkan oleh Islam. Lebih daripada itu ada beberapa aspek di luar pemenuhan kebutuhan biologis yang juga perlu diperhatikan, mulai dari kesiapan ekonomi, kematangan fisik, kedewasaan psikis, dan sebagainya dengan maksud agar tujuan perkawinan dapat dicapai dalam membina rumah tangga. ${ }^{1}$

Persoalan ini menjadi salah satu alasan ditetapkannya Undang-Undang Nomor 1 Tahun 1974 (selanjutnya disebut Undang-Undang Perkawinan), di mana salah satu bentuk aturannya menghendaki kesiapan dan kematangan calon mempelai. Pasal 7 ayat (1) Undang-Undang Perkawinan menyebutkan, "perkawinan hanya diizinkan bila pihak pria mencapai umur 19 (sembilan belas) tahun dan pihak wanita sudah mencapai usia 16 (enam belas) tahun." "2 Namun seiring perjalannya waktu dan kondisi sosial di masyarakat yang telah berubah, batas usia perkawinan dinilai terlalu rendah dan justru melahirkan permasalahan-permasalahan baru, baik permasalahan yang bersifat teoretik

${ }^{1}$ MA. Sahal Mahfudh, Pesantren Mencari Makna, (Jakarta: Pustaka Ciganjur, 1999), hlm. 110. 2Pasal 7 ayat (1) undang-undang No. 1 tahun 1974. 
Moh Luthfi Hakim

maupun bersifat praktik. Walaupun secara tegas Undang-Undang Perkawinan juga menyebutkan seseorang harus mendapatkan izin orang tua jika ia belum mencapai usia 21 tahun. $^{3}$

Setiap anggota keluarga mempunyai kewajiban memenuhi kebutuhan keluarga untuk meraih kesejahteraan. Seorang suami sebagai kepala keluarga memiliki kewajiban memenuhi kebutuhan istri dan anak-anaknya, baik kebutuhan pokok seperti kebutuhan sandang, papan, dan pangan, serta kebutuhan penunjang lainnya. Semua aspek tersebut merupakan komponen yang apabila dipadukan secara proporsional akan melahirkan kesejahteraan keluarga yang menjadi salah satu tujuan perkawinan. ${ }^{4}$ Agar dapat memenuhi kewajiban tersebut dengan baik, suami dituntut mempunyai al-ba'ah dalam arti kemampuan bersetubuh dan mencukupi segala kebutuhan keluarga sebagai kunci utama untuk mewujudkan keluarga yang bahagia dan sejahtera. ${ }^{5}$ Aspek al-ba'ab inilah yang belum cukup dimiliki oleh seseorang yang masih dalam usia remaja.

Secara yuridis, usia 16 tahun yang ditetapkan Undang-Undang Perkawinan sangat kontradiksi dengan Undang-Undang No. 35 tahun 2014 tentang perlindungan anak. ${ }^{6}$ Satu sisi Undang-Undang Perlindungan Anak menghendaki adanya perlindungan terhadap hak-hak anak, namun pada saat bersamaan Undang-Undang Perkawinan yang mengatur batas usia perkawinan menetapkan batas usia dibawahnya. Pasal 1 ayat (1) Undang-Undang Perlindungan Anak menyebutkan, "anak adalah seseorang yang belum berusia 18 tahun, termasuk anak yang masih dalam kandungan.”

Berdasarkan Undang-Undang Perlindungan Anak tersebut, perempuan yang menikah pada usia 16 tahun sama halnya mengambil hak-hak mereka untuk hidup dan berkembang dengan baik. Di samping kontradiktif dengan Undang-Undang Perlindungan Anak, juga bertentangan dengan Undang-Undang Nomor 12 Tahun 2003 tentang Ketenagakerjaan, Undang-Undang Nomor 3 Tahun 1997 tentang Pengadilan Anak, dan Pasal 1 angka 5 Undang-Undang Nomor 39 Tahun 1999 tentang Hak Asasi Manusia yang mendefinisikan anak sebagai setiap orang yang berumur di bawah 18

${ }^{3}$ Pasal 6 ayat (2) undang-undang No. 1 tahun 1974.

${ }^{4}$ MA. Sahal Mahfudh, Nuansa Fiqh Sosial, Cet. VII, (Yogyakarta: LkiS, 2011), hlm. 10.

${ }^{5}$ MA. Sahal Mahfudh, Nuansa Figh Sosial, hlm. 11.

'Perubahan atas undang-undang No. 23 tahun 2002 tentang perlindungan anak. 
tahun. Penetapan usia anak yang berbeda juga ditemukan dalam pasal 1 angka 2 Undang-Undang Nomor 4 Tahun 1979 tentang Kesejahteraan Anak yang menyebutkan bahwa anak adalah setiap orang yang belum mencapai umur 21 tahun.

Implikasi lain atas perkawinan usia muda juga banyak terjadi di masyarakat. Salah satu contoh masalah yang muncul yaitu dampak pada kesehatan, terutama kehamilan prematur yang bisa menjadi sebab kematian ibu. Dampak lainnya yaitu berpotensi terhadap tingginya angka perceraian, karena mental suami dan istri belum cukup matang untuk menyelesaikan masalah rumah tangga. Di sisi lain juga mengakibatkan pendidikan terputus, ekonomi terhambat, dan perkembangan pribadi terkendala. ${ }^{7}$

Gambaran tersebut di atas menjadi alasan kuat yang melatarbelakangi bahwa batas usia perkawinan penting dikaji kembali. Kendati perkawinan usia muda pernah dipraktikkan oleh Nabi Muhammad SAW dengan 'Aisyah, tetapi perkawinan pada usia muda tidak bisa begitu saja dijadikan patokan mengingat kondisi sosial masyarakat sudah mengalami perubahan. Dalam hal ini fiqh senantiasa harus berkembang agar sesuai dengan konteks yang sedang berjalan. Sebab fiqh harus mengacu pada aspek kemaslahatan sebagai bahan pertimbangannya, termasuk persoalan batas usia perkawinan.

Dalam penelitian ini, peneliti akan fokus dan mengkaji batas minimal usia perkawinan dalam Undang-Undang Perkawinan dengan menggunakan konsep fiqh sosial yang digagas oleh KH. MA. Sahal Mahfudh. Paradigma fiqh sosial memandang bahwa fiqh harus dibaca sebagai sarana untuk memecahkan permasalahan serta untuk merealisasikan kemaslahatan umum (al-mașlahah al-ämmah), yang berbentuk primer (dlarüriyyah), sekunder (häjizyyah), maupun tersier (tahsāniyyah). ${ }^{8}$

Dalam operasionalnya, konsep fiqh sosial dilakukan dengan cara pengembangan qauli dan pengembangan manbaji. Secara qauli pengembangan fiqh dilakukan dengan upaya kontekstualisasi kitab kuning melalui pengembangan contoh-contoh aplikasi kaidah-kaidah usul fiqh maupun qawāid al-fiqhyiyah. Sementara secara manhaji bisa

7http://www.kpai.go.id/2014/03/15/artikel/pernikahan-dini-dan-penjualan-anak/, diakses pada tanggal 26 April 2019.

${ }^{8}$ MA. Sahal Mahfudh, Nuansa Figh Sosial, hlm. xxxvi. 
Moh Luthfi Hakim

dilakukan melalui pengembangan teori masälik al-'illat.' Pada tahun 1974 batas usia perkawinan dalam Undang-Undang Perkawinan pada hakikatnya sudah mencerminkan adanya kontekstualisasi teks-teks fiqh, hanya saja konteks tahun tersebut sudah berbeda dengan konteks sekarang.

\section{B. Landasan Teori}

a. Karakteristik Fiqh Sosial

Hukum Islam yang berkembang di masyarakat tidak hanya digunakan sebagai alat untuk mengukur persoalan halal dan haram, tetapi pada pihak lain juga berfungsi sebagai rekayasa sosial. Dalam istilah ilmu hukum dikenal dengan fungsi ganda hukum, dimana hukum berfungsi sebagai social control dan social engineering. ${ }^{10}$

Secara bahasa, fiqh sosial terdiri dari dua kata yaitu fiqh dan sosial. ${ }^{11}$ Fiqh merupakan bentuk mașdar dari bahasa arab faqiha-yafqabu-fiqhan, yang berarti al-fahm yaitu paham atau mengerti. Dalam definisi terminologis, fiqh diartikan sebagai ilmu (hukum Islam) yang bersangkutan dengan segala bentuk amaliah manusia yang digali dari dalil-dalil yang terperinci. ${ }^{12}$ Sementara kata sosial merupakan terjemah dari bahasa Inggris "social" yang berarti peramah, senang bergaul, atau kemasyarakatan. Ketika diserap ke dalam bahasa Indonesia, kata sosial memiliki arti bersinggungan dengan masyarakat, serta ada juga yang mengartikan dengan perhatian terhadap kepentingan umum. ${ }^{13}$

Menurut Umdatul Baroroh dan Tutik Nurul Janah, kata sosial dalam istilah fiqh sosial bukan merupakan ajektif (susunan șifat-mausüf yang berfungsi sebagai pelengkap dari kata pertama), tetapi lebih tepat sebagai susunan frasa atau ị̂äfah dalam gramatikal bahasa Arab. Susunan ị̂äfah memiliki maksud untuk menyandarkan kata benda yang satu dengan kata benda lainnya sehingga membentuk kesatuan makna baru. Dengan demikian, maka fiqh sosial didefinisikan sebagai hukum Islam yang bersangkutan

${ }^{9}$ MA. Sahal Mahfudh, Nuansa Fiqh Sosial, hlm. xxvi.

${ }^{10}$ MA. Sahal Mahfudh, Nuansa Figh Sosial, hlm. liii.

${ }^{11}$ Umdatul Baroroh dan Tutik Nurul Janah, Fiqh Sosial: Masa Depan Fiqh Indonesia, (Pati: PUSAT FISI Institut Pesantren Mathali'ul Falah, 2016), hlm. 40.

${ }^{12}$ Muhammad bin Qasim al-Ghazy, Fath al-Qarīb al-Mujīb, (Jakarta: Dar al-Kutub al-Islamiyah, t.t), hlm. 9.

${ }^{13}$ Umdatul Baroroh dan Tutik Nurul Janah, Fiqh Sosial: Masa Depan Figh Indonesia, hlm. 40 
dengan segala bentuk amaliah manusia yang digali dari dalil-dalil terperinci untuk kemaslahatan umat.

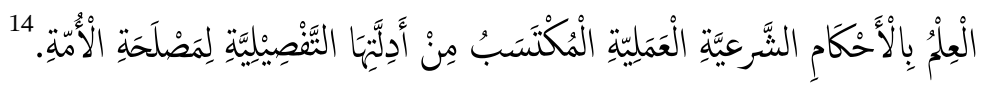

Definisi di atas memberikan arti bahwa fiqh adalah produk ijtihad yang dipengaruhi oleh realitas empiris, ruang dan waktu, sehingga menjadi keniscayaan bahwa hukum akan mengalami perkembangan dan pembaharuan. Sebab bagaimanapun hukum harus bermuara pada terwujudnya keadilan dan kesejahteraan sehingga tujuan aplikasi syari'ah dapat diwujudkan, yaitu kemaslahatan di dunia dan akhirat.

Sementara itu, berdasarkan hasil halaqah Nahdlatul Ulama (NU) bekerjasama dengan Rabithah Ma'ahid Islamiyah (RMI-NU) dan Pusat Pengembangan Pesantren dan Masyarakat (P3M), fiqh sosial memiliki lima karakteristik atau ciri pokok, yaitu: ${ }^{15}$ Pertama, kontekstualisasi terhadap teks-teks fiqh. Pemahaman kitab kuning harus sesuai dengan konteksnya, baik konteks masa lalu saat kitab tersebut dikodifikasikan maupun konteks permasalahan yang sedang dihadapi saat ini. Kedua, beralih dari cara bermadzhab secara qauli ke manhaji. Bermadzhab secara qauli berarti mengikuti produk fiqh, sedangkan bermadzhab secara manhaji adalah menggunakan ushul fiqh. Ketiga, verifikasi mana ajaran yang $u\langle\grave{u} l$ dan mana ajaran yang furû́. Keempat, menjadikan fiqh sebagai etika sosial bukan hukum positif negara, dalam arti pergeseran pemahaman fiqh yang tekstual formalistik menjadi fiqh yang etik. ${ }^{16}$ Kelima, menggunakan pemikiran filosofis, terutama dalam masalah sosial budaya. Aplikasi pemikiran filosofis memberikan kemungkinan untuk pengembangan kerangka metodologis fiqh sosial yang lebih kuat.

b. Istimbath Hukum Fiqh Sosial: Madzhab Qauly dan Manhaji

Dalam aplikasinya terdapat dua model pendekatan yang digunakan oleh fiqh sosial. Secara eksplisit Kiai Sahal menjelaskan landasan dasar metodologi fiqh sosial, yaitu: "Secara qauli pengembangan fiqh bisa diwujudkan dengan melakukan kontekstualisasi kitab kuning atau melalui pengembangan contoh-contoh aplikasi kaidah-kaidah usul

${ }^{14}$ Umdatul Baroroh dan Tutik Nurul Janah, Fiqh Sosial: Masa Depan Fiqh Indonesia, hlm. 41.

${ }^{15}$ MA. Sahal Mahfudh, Nuansa Figh Sosial, hlm. viii.

${ }^{16}$ MA. Sahal Mahfudh, Nuansa Figh Sosial, hlm. ii. 
Moh Luthfi Hakim

fiqh maupun qawa'id al-fiqhiyah. Sedangkan secara manbaji pengembangan fiqh bisa dilakukan dengan cara pengembangan teori masälik al-illah agar fiqh yang dihasilkan sesuai dengan al-mașlahah al-'ämmah." ${ }^{17}$ Pengembangan fiqh sosial selalu memegang prinsip "al-muhäfạahb 'alā al-qadìm al-șälih wa al-akhdh bi al-jadìd al-aṣlah,"18 yaitu mempertahankan tradisi lama yang relevan dan mengambil tradisi baru yang lebih progresif.

Kitab-kitab fiqh yang sering digunakan oleh Kiai Sahal adalah kitab-kitab yang ditulis oleh ulama Syafi'iyyah. Sejumlah kitab yang sering dijadikan rujukan dalam menyelesaikan problem hukum yaitu al-Muhadhdhab, al-Majmu', Nihāyāh ₹-Zain, Subul asSalàm, Mì̃àn al-Kubra, Fath al-Mu'in, al-Bäjuri, al-Umm, ar-Risālah, Al-Ashbāh wa anNậaì, dan lain-lain. Sementara ulama yang sering dijadikan referensi adalah Al-Rifa’i (w. $623 \mathrm{H}$ ), Al-Nawawi (w. $627 \mathrm{H}$ ), Al-Razi (w. $1606 \mathrm{H}$ ), al-Mawardi (w. $450 \mathrm{H}$ ), alJuwaini (w. 478 H), al-Ghazali (w. 505), al-Muzani (w. 264 H). ${ }^{19}$

Salah satu contoh pendekatan fiqh sosial adalah aplikasi kaidah fiqhiyah idha ta'äradla mafsadatāni ru'iya a'damubumā d̦lararan bi irtikeäbi akhaffihimā dalam konteks lokalisasi prostitusi. Kiai Sahal dalam hal ini lebih memilih melokalisir prostitusi dibanding membiarkan tidak terkontrol sehingga menimbulkan bahaya (mudarat) yang lebih besar. Meskipun dalam Islam tidak terdapat satu pun alasan untuk menghalalkan zina, namun sebagai masalah sosial dimana persoalan prostitusi sulit dihilangkan, maka pilihan membenarkan lokalisasi dapat menjadi salah satu solusi dengan maksud agar pemerintah dapat melakukan pengawasan, pencegahan masifnya seks bebas dan menyelamatkan daerah lain tertular penyakit ini. ${ }^{20}$ Apabila mengamati dengan seksama, lokalisasi sebenarnya merupakan strategi untuk menghindari praktik prostitusi berkeliaran di sembarang tempat. Menempatkan prostitusi pada satu tempat dapat membuat pemerintah lebih mudah melakukan kontrol kesehatan dan membekali skill

${ }^{17}$ MA. Sahal Mahfudh, Nuansa Fiqh Sosial, hlm. xxvi.

${ }^{18}$ MA. Sahal Mahfudh, Nuansa Fiqh Sosial, hlm. xxxvii.

${ }^{19}$ Sumanto al-Qurtuby, KH. MA. Sahal Mahfudh: Era Baru Fiqh Pesantren, (Semarang: Elsa Press, 2017), hlm. 111-112.

${ }^{20}$ MA. Sahal Mahfudh, Nuansa Figh Sosial, hlm. XIIV. 
bekerja, sehingga para pihak yang terlibat di dalamnya secara bertahap dapat keluar dari profesi tersebut.

Dalam konteks pembatasan usia perkawinan pengembangan bermazhab qauli sangat mungkin diaplikasikan, tentu dengan melihat terlebih dahulu sejumlah aspek yang berhubungan, mulai dari aspek internal seperti kematangan fisik, psikis, kematangan ekonomi, pendidikan dan skill yang dimiliki oleh calon mempelai, serta aspek-aspek eksternal yang mempengaruhi. Selanjutnya melakukan aplikasi kaidah ușüliyyah atau kaidah fiqhiyyah terhadap pembatasan usia perkawinan, apakah batas minimal usia tersebut masih relevan diterapkan di tengah kondisi masyarakat Indonesia saat ini untuk mewujudkan tujuan perkawinan.

Sedangkan metode manhaji melalui pengembangan masâlikul illat dilakukan dengan integrasi hikmah hukum ke dalam illat hukum dalam qiyas, dengan demikian pemahaman qiyas akan berorientasi pada tujuan aplikasi syariah (maqāṣid as-sharìah). ${ }^{21}$ Maqāṣid as-sharìah yang merupakan substansi hukum akan menjadi pertimbangan dalam menetapkan hukum. Pemeliharaan terhadap agama, jiwa, akal, harta, dan keturunan menjadi indikasi tercapainya kemaslahatan umum.

Ulama ushul mendefinisikan masälik al-illat sebagai metode yang digunakan untuk mengidentifikasi adanya 'illat yang digunakan dalam penetapan hukum. Adapun cara untuk menemukan ada tidaknya 'illat tersebut bisa dilakukan melalui beberapa tahapan. Pertama, melalui nash al-Qur'an atau hadis. Kedua, ijma' (konsensus) ulama. Ketiga, ijtihad dengan melihat keselarasan antara 'illat dan hukum (al-munāsabah) atau dengan uji coba dan verifikasi (as-sabr wa at-taqsim). Wilayah pengembangan masalik al-illat inilah yang menjadi lapangan ijtihad dalam fiqh sosial. ${ }^{22}$

Bermadzhab secara manhaji fiqh sosial, selain dilakukan dengan pengembangan masälik al-illat, juga dilakukan dengan mendiskusikan konsep-konsep ushul fiqh, seperti mașlahah, sadd adh-dharìah, istihsān, al-urf, dan lain-lain. Hal ini dikarenakan banyak

${ }^{21}$ MA. Sahal Mahfudh, Nuansa Figh Sosial, hlm. II.

${ }^{22}$ Umdatul Baroroh dan Tutik Nurul Janah, Figh Sosial: Masa Depan Fiqh Indonesia, hlm. 75. 
Moh Luthfi Hakim

persoalan-persoalan hukum yang terjadi sekarang ini tidak ditemukan padanannya dalam teks fiqh klasik. ${ }^{23}$

Disamping mengintegrasikan "illat dan hikmah hukum, integrasi dengan disiplin ilmu-ilmu lain (di luar fiqh dan ushul fiqh) juga dibutuhkan, baik ketika menerapkan pola pengembangan bermadzhab qauli maupun pengembangan bermadzhab manhaji. ${ }^{24}$ Namun perlu digaris bawahi bahwa pengertian istinbät al-ahkäm dalam fiqh sosial bukan bermakna mengambil hukum dari sumber al-Qur'an dan Hadis secara langsung, melainkan mengarahkan pada tațiq (mengimplemtasikan) secara dinamis nash-nash fuqaha dalam konteks permasalahan yang sedang dicari solusi hukumnya. ${ }^{25}$

Dari uraian di atas dapat diketahui bahwa rumusan metodologi fiqh sosial dalam istinbät al-ahkām ada dua. Pertama, pengembangan bermadzhab qauli yang diwujudkan dengan cara kontekstualisasi teks-teks fiqh dan mengembangkan aplikasi contohcontoh kaidah uṣüliyyah dan fiqhiyyah. Kedua, adalah bermadzhab manhaji melalui integrasi illat hukum dan hikmah hukum (maqāṣid as-sharīah). Berikut tabel pendekatan fiqh sosial:

\begin{tabular}{|c|c|c|c|c|}
\hline 1 & $\begin{array}{l}\text { Pengembangan } \\
\text { madzhab qauli }\end{array}$ & $\begin{array}{l}\text { - Dengan cara pemahaman fiqh } \\
\text { klasik secara kontekstual melalui } \\
\text { pengembangan contoh-contoh } \\
\text { aplikasi kaidah ușüliyyah dan } \\
\text { fiqhiyyah. } \\
\text { - Integrasi dengan disiplin ilmu- } \\
\text { ilmu lain yang dibutuhkan (eksak } \\
\text { ataupun sosial). }\end{array}$ & $\rightarrow$ & $\begin{array}{c}\text { Menjadikan al- } \\
\text { Mașlahah al-ämmah } \\
\text { (kemaslahatan } \\
\text { umum) sebagai } \\
\text { pertimbangan } \\
\text { dalam menetapkan } \\
\text { hukum }\end{array}$ \\
\hline 2 & $\begin{array}{l}\text { Pengembangan } \\
\text { madzhab manhaji }\end{array}$ & $\begin{array}{l}\text { - Pengembangan teori masälik al- } \\
\text { illat dengan mengintegrasikan } \\
\text { hikmah hukum (kemaslahatan) ke } \\
\text { dalam 'illat hukum. }\end{array}$ & & \\
\hline
\end{tabular}

Dalam menganalisa permasalahan ini, penulis akan menggunakan metode fiqh sosial berupa pengembangan madzhab qauli, yaitu melakukan kontekstualisasi kitabkitab fiqh yang membahas batas usia perkawinan dan penerapan kaidah fiqbiyyah dengan

\footnotetext{
${ }^{23}$ MA. Sahal Mahfudh, Mengaktualkan Fiqh Klasik di Era Global dalam Epistemologi Fiqh Sosial, (Pati: Fiqh Sosial Institute, 2014), hlm. xvi.

${ }^{24}$ MA. Sahal Mahfudh, Nuansa Fiqh Sosial, hlm. xlii.

${ }^{25}$ MA. Sahal Mahfudh, Nuansa Fiqh Sosial, hlm. 28
} 
melihat kemaslahatan publik sebagai pertimbangan utamanya, serta integrasi dengan disiplin ilmu psikologi perkembangan. Selanjutnya melakukan analisa menggunakan madzhab manbaji fiqh sosial melalui pengembangan teori masälik al-ïlat dengan mengintegrasikan hikmah hukum (kemaslahatan publik) ke dalam 'illat hukum.

\section{Metode Penelitian}

Penelitian ini termasuk dalam kategori penelitian hukum normatif dengan menjadikan ketentuan batas usia perkawinan sebagai obyek penelitian. Disamping juga fokus terhadap asas serta doktrin hukum, sistematika hukum, perbandingan dan sejarah hukum terkait pembatasan usia perkawinan. ${ }^{26}$ Dalam penelitian ini penulis menggunakan pendekatan konseptual (conceptual approacb). ${ }^{27}$ Pendekatan konseptual dimaksudkan untuk menemukan ide-ide yang melatarbelakangi lahirnya konsep serta asas yang relevan dengan tema pembatasan usia perkawinan. Hal ini akan menjadi landasan dan argumen dalam memecahkan persoalan batas usia perkawinan yang sedang diteliti.

Berbeda dengan jenis penelitian lainnya, sumber data dalam penelitian hukum normatif lebih dikenal dengan istilah bahan hukum, meliputi bahan hukum primer, sekunder dan tersier. ${ }^{28}$ Bahan hukum primer dalam penelitian ini adalah UndangUndang No.1 Tahun 1974 tentang perkawinan dan buku berjudul Nuansa Fiqh Sosial karangan KH. MA. Sahal Mahfudh. Selain bahan hukum primer, terdapat juga bahan hukum sekunder berupa buku berjudul Pesantren Mencari Makna, buku Mengembangkan Fiqh Sosial, dan buku Fiqh Sosial Masa Depan Fiqh Indonesia. Sementara, bahan hukum tersiernya yaitu kamus Al-Bisri dan kamus Al-Munawwir.

Teknik pengumpulan data dilakukan dengan menggunakan metode dokumentasi (bahan pustaka). ${ }^{29}$ Dokumen-dokumen yang dimaksud adalah data atau bahan yang memuat permasalahan pembatasan usia perkawinan, berupa peraturan perundang-

\footnotetext{
${ }^{26}$ Abdul Kadir Muhammad, Hukum dan Penelitian Hukum, (Bandung: PT. Citra Aditya Bakti, 2004), hlm. 52. ${ }^{27}$ Peter Mahmud Marzuki, Penelitian Hukum, (Jakarta: Kencana, 2007), hlm. 95.

${ }^{28}$ Amiruddin dan Zainal Asikin, Pengantar Metode Penelitian Hukum, (Jakarta: Rajawali Pers, 2006), hlm. 31-32.

${ }^{29}$ Suharsimi Arikunto, Prosedur Penelitian (Suatu Pendekatan Praktik), (Jakarta: Rineka Cipta, 2006), hlm. 231.
} 
Moh Luthfi Hakim

undangan. Kemudian menganalisis data tersebut sesuai dengan permasalahan dan tujuan penelitian ini.

Selanjutnya langkah analisis data dilakukan dengan cara mendeskripsikan dan menganalisa pasal 7 ayat (1) Undang-Undang Nomor 1 Tahun 1974 yang tidak bisa terlepas dari penafsiran. ${ }^{30}$ Dalam penelitian ini akan ditemukan latar belakang serta tujuan dibuatnya undang-undang kemudian menganalisanya secara tepat dengan menggunakan pendekatan Fiqh Sosial.

\section{Hasil dan Pembahasan}

a. Batas Usia Perkawinan dalam Undang-Undang Perkawinan

Pembatasan usia perkawinan dalam Undang-Undang Perkawinan sudah sepatutnya bermuara pada kemaslahatan umum, yaitu terciptanya kehidupan tenteram di dunia juga akhirat. Dalam kajian sejarah legislasi Undang-Undang Perkawinan, pembatasan usia perkawinan merupakan bentuk usaha yang dilakukan pemerintah untuk mencegah praktik-praktik perkawinan anak yang marak terjadi di Indonesia. ${ }^{31}$

Batas usia perkawinan di Indonesia diatur secara tegas dalam pasal 7 ayat (1) Undang-Undang Nomor 1 Tahun 1974. Undang-Undang tersebut menyebutkan bahwa perkawinan hanya diizinkan bila pihak pria minimal telah berusia 19 tahun dan pihak wanita sekurang-kurangnya berusia 16 tahun. Hampir tidak ada multi tafsir dalam peraturan perundang-undangan tersebut di atas, sangat jelas bermakna bahwa usia yang diperbolehkan untuk melangsungkan perkawinan yaitu minimal usia 19 tahun bagi lakilaki dan usia 16 tahun bagi calon pengantin wanita. Namun, masih ada syarat tambahan dalam praktiknya masih ada yaitu jika calon pengantin pria dan calon pengantin wanita belum mencapai usia 21 tahun, mereka mendapat restu serta izin tertulis dari orang tua atau wali nikah. ${ }^{32}$

Kompilasi Hukum Islam (KHI) dalam posisinya sebagai legitimasi hukum yang berlaku khusus bagi penduduk muslim Indonesia secara umum bersifat memperkuat

\footnotetext{
${ }^{30}$ Amiruddin dan Zainal Asikin, Pengantar Metode Penelitian Hukum, hlm. 163.

${ }^{31}$ Abdul Halim, Politik. Hukum Islam di Indonesia, (Jakarta: Badan Litbang dan Diklat Departemen Agama RI, 2008), hlm. 190.

32Pasal 6 ayat (2) undang-undang Nomor 1 Tahun 1974.
} 
apa yang sudah ditetapkan oleh Undang-Undang Perkawinan terkait dengan batas usia perkawinan. KHI dalam hal ini hanya menambahkan pertimbangan hukum yang mendasari ditetapkannya pembatasan usia tersebut yang tidak lain adalah sebagai upaya kemaslahatan umum. Secara lengkap KHI Pasal 15 ayat (1\&2) menjelaskan sebagai berikut:

1) Untuk kemaslahatan keluarga dan rumah tangga, perkawinan hanya boleh dilakukan calon mempelai yang telah mencapai umur yang ditetapkan dalam pasal 7 UndangUndang Nomor 1 Tahun 1974 yakni calon suami sekurang-kurangnya berumur 19 tahun dan calon isteri sekurang-kurangnya berumur 16 tahun.

2) Bagi calon mempelai yang belum mencapai umur 21 tahun harus mendapati izin sebagaimana yang diatur dalam pasal 6 ayat (2), (3), (4) dan (5) Undang-Undang Nomor 1 tahun 1974.

Hanya saja seiring dengan perubahan jaman, batas minimal usia perkawinan dianggap masih belum sesuai dengan kompleks persoalan rumah tangga yang dihadapi pada saat ini. Kemudian muncul pertanyaan apakah usia 16 tahun bagi wanita dan 19 tahun bagi pria sudah dipandang cukup dewasa dan ideal untuk membina kehidupan rumah tangga. Meskipun sebenarnya baik Undang-undang Perkawinan maupun Kompilasi Hukum Islam telah menjelaskan asas-asas utama yang harus dipenuhi dalam perkawinan, salah satu asas yang sangat penting yaitu asas kematangan atau kedewasaan calon mempelai, sebagaimana yang juga diterapkan oleh beberapa negara muslim lainnya dengan kebijakan batas usia perkawinan yang tidak sama. ${ }^{33}$

Adanya perbedaan masing-masing negara dalam menetapkan batas minimal usia perkawinan bukan tanpa alasan, sebab setiap lahirnya kebijakan dan hukum tertentu pasti dipengaruhi oleh faktor-faktor yang melatarbelakanginya. Begitu pun dengan batas usia perkawinan dalam Undang-Undang Nomor 1 Tahun 1974, tentu masuk pada tataran ini, yaitu dipengaruhi oleh aspek sosial, politik, agama, ekonomi dan budaya yang berlaku di Indonesia. ${ }^{34}$

\footnotetext{
${ }^{33}$ Muhammad Amin Summa, Hukum Keluarga Islam di Dunia Islam, (Jakarta: Raja Grafindo Persada, 2004), hlm. 183.

${ }^{34}$ Marzuki Wahid, Fiqh Indonesia: Kompilasi Hukum Islam dan Counter Legal Draft Kompilasi Hukum Islam dalam Bingkeai Politik. Hukum Indonesia (Bandung: Marja, 2014), hlm. 50.
} 
Moh Luthfi Hakim

b. Aplikasi Madzhab Qauli Fiqh Sosial terhadap Batas Usia Perkawinan Dalam UndangUndang No 1 Tahun 1974

1) Kontekstualisasi terhadap Teks-Teks Fiqh tentang Usia Perkawinan

Masih secara implisit pembahasan secara spesifik di kalangan ahli fiqh klasik mengenai batas usia perkawinan. Dalam literatur fiqh klasik hanya dibicarakan bahwa baligh sebagai salah satu syarat calon mempelai dengan beragam definisi yang berbeda. Meskipun para ahli fiqh berbeda dalam memaknai usia baligh, tetapi yang perlu diperhatikan ialah bagaimana teks-teks fiqh tersebut dapat dimaknai secara kontekstual dengan cara melihat konteks yang terjadi pada masa lampau serta bagaimana dengan konteks saat ini. Pemahaman seperti inilah yang dalam fiqh sosial disebut dengan "kontekstualisasi terhadap teks-teks kitab kuning" agar literatur fiqh tetap relevan dengan perkembangan jaman. ${ }^{35}$

Secara umum, ada lima hal yang menjadi ukuran seseorang disebut baligh. Tiga hal dimiliki oleh baik pria maupun wanita, sementara dua lainnya yaitu menstruasi dan kehamilan hanya ada pada wanita. ${ }^{36}$ Baligh yang ditandai dengan batasan usia, menurut imam Syafi'i, Auza'i dan Muhammad ibn Hanbal menyatakan bahwa baligh bagi lelaki maupun wanita yaitu usia 15 tahun. Menurut imam Malik adalah usia 17 tahun baik bagi laki-laki maupun perempuan. Sedangkan Imam Abu Hanifah berpendapat bahwa usia baligh seseorang itu mulai umur 17 atau 18 tahun bagi laki-laki dan 17 tahun bagi perempuan dalam segala kondisi. ${ }^{37}$ Imam Nawawi salah satu ulama Syafi'iyah juga mendefinisikan bahwa baligh adalah seseorang yang secara fisik telah sampai usia 15 tahun dan secara akal telah matang. ${ }^{38}$

Selain kematangan fisik, kematangan dalam hal mental-psikis juga menjadi pertimbangan dalam mendefinisikan kedewasaan. Penjelasan ini secara tersirat terangkum dalam al-Qur'an surat an-Nisa' (4) ayat 6. Dalam ayat tersebut setelah kalimat hattā idhā balaghü an-nikēh diikuti oleh lafal 'rushdan'. Penyebutan kata 'rushdan'

${ }^{35}$ MA. Sahal Mahfudh, Nuansa Figh Sosial, hlm. xlii.

${ }^{36}$ Muhammad bin Ahmad bin Abu Bakar al-Qurtuby, al-Jāmi' Li Abkām al-Qur'ān, Juz 6, (Beirut: ar-Risalah, t.t.). hlm. 61-62.

${ }^{37}$ Abdullah bin Ahmad bin Muhammad bin Qudamah, al-Mughny, juz 6, (Riyadh: Dar alam al-kutub, 1997), hlm. 598.

38Muhammad bin Umar Nawawi al-Jawi, Nihāyāt až-Zain, (Beirut: Dar al-Kutub al-Ilmiyah, 2002), hlm. 242.

\section{9}


bukan tanpa arti, artinya bahwa baligh selain diukur dari aspek fisik juga dari aspek psikis. Kata 'rushdan' dalam pandangan imam Hasan dan Qatadah adalah kematangan akal dan agama. Sedangkan ulama lainnya seperti Ibnu Abbas dan Tsauri berpendapat bahwa 'rushdan' berarti matang secara akal dan memiliki kemampuan pengelolaan harta yang mencukupi. ${ }^{39}$

Adanya tuntutan kedewasaan calon mempelai pria dan wanita juga ditemukan dalam hadist yang berbunyi:

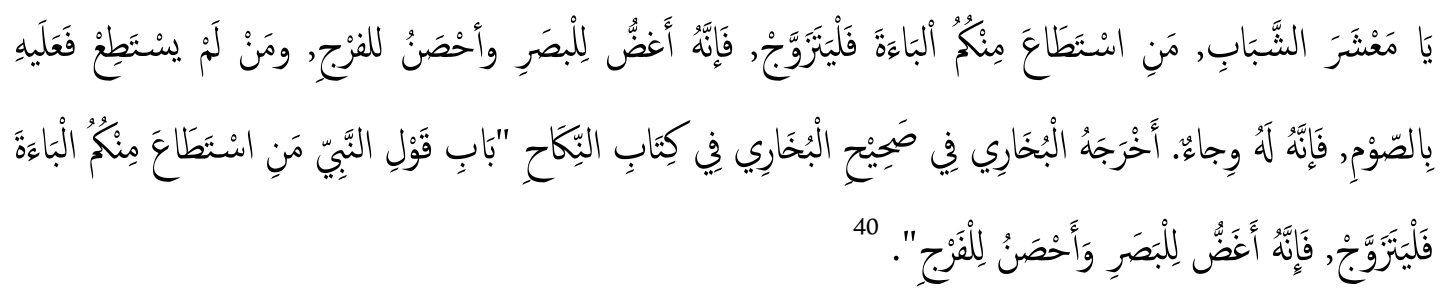

Artinya: Wahai para pemuda, barangsiapa diantara kamu yang sudah mampu menikah, maka menikahlah, sesungguhnya ia lebih menjaga pandangan dan memelihara kemaluan, dan barangsiapa tidak mampu, hendaklah berpuasa, sesunggubnya ia sebagai perisai baginya.

Pemahaman kontekstual terhadap teks fiqh yang berbicara mengenai batas usia perkawinan adalah sebuah keharusan. Baligh sebagai salah satu syarat calon pengantin tidak boleh hanya dipahami secara tekstual. Asumsi yang mestinya dibangun adalah bahwa usia baligh harus mengacu pada dimensi yang menyeluruh baik aspek internal maupun eksternalnya, karena hal tersebut erat hubungannya dengan pemenuhan hak dan kewajiban dalam berumah tangga. ${ }^{41}$ Adanya syarat baligh bagi kedua calon mempelai dalam perkawinan tidak lain adalah agar pasangan tersebut dapat mengarungi kehidupan berumah tangga sesuai dengan yang disyariatkan oleh Islam. Dengan paradigma tersebut, batasan usia seseorang siap secara psikis dan fisik akan sangat ditentukan oleh perubahan waktu, struktur dan kultur masyarakat di mana mereka hidup dan bertempat tinggal.

Dalam operasionalnya, langkah yang diperlukan dalam upaya kontekstualisasi teksteks fiqh yaitu dengan membuka diri dengan disiplin ilmu diluar fiqh. Dengan demikian

${ }^{39}$ Muhammad bin Ahmad bin Abu Bakar al-Qurtuby, al-Jāmi' Li Abkām al-Qur'ān, hlm. 65.

40Imam al-Bukhari, Șaḥh al-Bukhāry, hadis nomor 5066, (Beirut: Dar Ibn Katsir, 2002), hlm. 1293.

${ }^{41}$ Kaharuddin, Nilai-Nilai Filosofi Perkawinan, (Jakarta: Mitra Wacana Media, 2015), hlm. 121. 
Moh Luthfi Hakim

pemahaman teks fiqh mengenai usia baligh akan relevan dengan konteks masa lalu dan sekarang. Integrasi tersebut akan menciptakan sinergi ilmiah yang akan memecahkan persoalan hukum, ${ }^{42}$ dalam hal ini batas usia perkawinan dalam Undang-Undang Perkawinan.

2) Integrasi Fiqh dengan Disiplin Ilmu di Luar Fiqh

Makna perkawinan yang disyariatkan oleh Islam tidak boleh dipandang sebagai pemenuhan terhadap kebutuhan biologis semata. Banyak orang yang hanya sampai pada pemahaman ini. Pemahaman yang demikian akan memberikan kesimpulan bahwa kedewasaan cukup pada sisi kematangan fisik kedua calon mempelai. Padahal banyak aspek lain yang sama pentingnya serta antara satu dan lainnya tidak bisa dipisahkan.

Untuk memahami keterkaitan antara aspek satu dengan yang lainnya, diperlukan adanya integrasi dan dialog antara fiqh dengan disiplin ilmu lain yang relevan untuk menentukan batas usia perkawinan yang tepat dalam Undang-Undang Perkawinan. Secara fisik dan psikis usia dewasa merupakan kondisi fisik seseorang sudah berkembang sempurna dan matang sehingga telah memiliki kekuatan maksimal, siap bereproduksi, siap dalam aspek kognitif, aspek afektif dan aspek psikomotor, dan mampu berinteraksi secara sosial dengan masyarakat. ${ }^{43}$ Singkatnya, dewasa adalah kondisi dimana seseorang baik dari aspek fisik maupun psikis dikatakan sudah matang. Meskipun antara satu individu dengan lainnya tidak sama, tetapi kebanyakan ahli psikologi sudah memberikan standart umum (usia dewasa) sebagai pijakan untuk mengetahui dewasanya seseorang, yaitu ketika telah berakhir masa adolesensi (pubertas akhir atau remaja akhir) pada saat itulah seseroang menginjak masa dewasa. Sementara mayoritas ahli psikologi menyatakan bahwa batas waktu adolesensi adalah usia 17-19 tahun atau 17-21 tahun. ${ }^{44}$

Usia dewasa biasanya dimulai sejak usia 21 atau 22 tahun, pada usia tersebut seseorang dipandang sudah mampu memikul tanggung jawab sebagai orang dewasa. ${ }^{45}$ Ada 3 (tiga) Fase dewasa dalam kajian ilmu psikologi perkembangan, yaitu pertama:

\footnotetext{
${ }^{42}$ MA. Sahal Mahfudh, Nuansa Figh Sosial, hlm. xlii.

${ }^{43}$ Andi Mappiare, Psikologi Orang Dewasa, (Surabaya: Usaha Nasional, 1983), hlm. 17.

${ }^{44}$ Kartini Kartono, Psikologi Anak (Psikologi Perkembangan), (Bandung : Mandar Maju, 1995), hlm. 182.

${ }^{45}$ Andi Mappiare, Psikologi Orang Dewasa, hlm. 19.
} 
dewasa awal yang terjadi saat seseorang berusia 20-an tahun sampai 30-an tahun. Kedua: dewasa menengah dialami seseorang ketika berusia 40-an sampai dengan usia 50-an tahun. Ketiga: dewasa akhir yaitu usia 60 -an tahun ke atas. ${ }^{46}$

Berdasarkan kacamata ahli psikologi perkembangan, usia 19 dan 16 tahun sebagai batas minimal usia perkawinan masih tergolong sebagai masa remaja akhir. Padahal ketika masa itu remaja dihadapkan pada berbagai persoalan yang berhubungan dengan perkembangan biologis dan psikologisnya. Tentu ini akan menjadi problem, satu sisi remaja sedang mengalami banyak masalah di dalam perkembangan mental, pada saat yang sama ia harus berusaha mencapai tujuan perkawinan. Diantara permasalahan yang umumnya terjadi pada masa remaja adalah: ${ }^{47}$

a) Remaja masih belajar mandiri dalam suasana kebebasan.

b) Remaja ingin bebas dari bimbingan orang tua dan pihak yang dianggap mengganggu kebebasannya.

c) Remaja mulai mengevaluasi relasi afektif lama dan menilai bahwa relasi yang baru lebih bernilai dibanding relasi afektif lama.

Di sisi lain remaja dalam perkembangannya dihadapkan dengan pilihan-pilihan sulit (konflik), berupa: ${ }^{48}$

a) Konflik antara kebutuhan untuk dapat mengendalikan dirinya dan kebutuhan akan rasa bebas dan merdeka. Remaja masih butuh bergantung kepada orang lain, da di sisi lain ia butuh akan rasa bebas.

b) Konflik antara kebutuhan ingin bebas dan kebutuhan ketergantungan terhadap orang tua atau keluarga sebagai penunjang materi untuk studi, usaha, atau kehidupan sosialnya, dan sebagainya.

c) Konflik antara kebutuhan seksual dan kebutuhan agama serta nilai-nilai kehidupan. Ditambah lagi, kematangan ekonomi untuk mampu membentuk keluarga pada umumnya baru tercapai ketika seseorang menginjak usia 24 tahun, sedangkan kematangan seksual terjadi pada remaja puteri 16 tahun dan remaja putera 18 tahun.

${ }^{46}$ John W. Santrock, Remaja, terjemah oleh penerbit Erlangga, (Jakarta : Erlangga, 2007), hlm. 50-51

${ }^{47}$ Kartini Kartono, Psikologi Anak (Psikologi Perkembangan), hlm. 184.

48Zakiah Daradjat, Remaja: Harapan dan Tantangan, (Jakarta: Ruhama, 1995), hlm. 60-63. 
Moh Luthfi Hakim

d) Konflik dalam menentukan masa depan. Pada tahap ini remaja akan mengalami kegoncangan jiwa yang sedemikian rupa.

Disamping itu, batas minimal usia perkawinan dalam undang-undang juga belum memiliki kesiapan dalam menghadapi fase gejolak dalam rumah tangga. Fase gejolak dalam kehidupan berumah tangga merupakan fase terpenting yang harus dilalui oleh pasangan suami istri sebelum sampai pada kondisi kebahagiaan yang sesungguhnya (sakinah). Fase ini menuntut kedewasaan kedua pasangan dalam memecah gejolak di dalam jiwa, jika gejolak ini tidak diselesaikan maka akan terancam gagal dalam membina rumah tangga, dan bukan tidak mungkin akan berakhir dengan perceraian. ${ }^{49}$

Implikasi lain yang timbul akibat perkawinan usia remaja adalah adanya kecenderungan menampakkan perasaan mawadah atau rasa cinta yang lebih didorong oleh ego syahwati manusia, padahal ada juga aspek rahmah yang tidak boleh terlupakan dalam kehidupan rumah tangga. Ketidakseimbangan antara mawadah dan rahmah sering berdampak negatif yang justru tidak membuahkan rasa tenteram (sakinah), dan sebaliknya justru memicu ketidakterbukaan antara suami istri, kecemburuan yang berlebihan, dan ketidakpercayaan. ${ }^{50}$

Oleh sebab itu mawadah (mahabbah thabi'iyah) dan rahmah (mahabbab 'aqliyyah) harus berjalan dengan proporsional. Cinta yang berlebihan akan melahirkan cemburu yang berlebihan juga, mudah marah dan tersinggung yang justru akan memicu timbulnya konflik antara suami istri. Kiai Sahal dalam hal ini menyatakan, "Mawadah seharusnya sebagai sumber inspirasi yang menumbuhkan sikap rahmah. Begitu pula sebaliknya, rasa rahmah menjadi sumber inspirasi yang menumbuhka sikap mawadah. Keduanya mempunyai hubungan mutualis-mutandis yang mampu menciptakan kerukunan, keharmonisan, dan kesakinahan yang sering diindikasikan dengan sikap hidup keluarga yang bila menghadapi masalah berat sama-sama mengangkat dan bila menghadapi masalah ringan sama-sama menjinjing seraya masing-masing menyadari dan memahami posisi dan potensinya yang langsung berimplikasi pada hak dan kewajiban masingmasing." $" 51$

${ }^{49}$ M. Quraish Shihab, Pengantin Al-Qur'an, (Jakarta : Lentera Hati, 2007), hlm. 90.

${ }^{50}$ MA. Sahal Mahfudh, Pesantren Mencari Makna, hlm. 112.

${ }^{51}$ MA. Sahal Mahfudh, Pesantren Mencari Makna, hlm. 113. 
Pada usia dewasa, perkembangan kognitifnya sudah matang dan sempurna sehingga seseorang dapat melaksanakan tanggung jawabnya (responbility stage). Dalam lingkup kehidupan rumah tangga, setiap anggota keluarga dituntut dapat melaksanakan kewajiban (tanggung jawab) sebagai konskuensi dari statusnya, suami memiliki kewajiban terhadap istrinya dan sebaliknya, demikian juga seorang ayah mempunyai kewajiban terhadap anaknya dan sebaliknya. Jadi yang disebut tanggung jawab pada usia dewasa adalah sikap tanggung jawab yang harus diwujudkan dalam setiap aspek kehidupan, berupa aspek lembaga sosial-pekerjaan maupun aspek lembaga sosial keluarga. ${ }^{52}$ Tidak hanya secara kognitif, pada masa dewasa orang telah memperlihatkan kesiapan biologis, kematangan psikologis dan dapat diharapkan untuk bertindak matang secara psikologis bersama-sama dengan orang dewasa lainnya dalam interkasi sosial. ${ }^{53}$

Dalam konteks masyarakat Indonesia saat ini, usia 19 tahun bagi laki-laki masih tergolong sangat muda untuk menjadi seorang suami yang bertanggung jawab sepenuhnya atas keluarganya. Kurangnya persiapan dari berbagai aspek kehidupan seperti kesiapan fisik, mental, dan ekonomi akan berakibat buruk di kemudian hari. Misalnya dalam hal ekonomi, suami dituntut mencukupi kebutuhan istri serta anaknya, dan itu merupakan hal utama. Apabila mengacu pada data remaja di Indonesia yang bekerja pada usia 15-19 tahun, maka pembatasan usia kawin masih terlalu rendah untuk diaplikasikan di Indonesia saat ini. BPS (Badan Pusat Statistik) mencatat bahwa remaja usia 15-19 tahun yang sudah bekerja baru sekitar 21,3\% dari total remaja sejumlah 24.074.997 (15-19 tahun), selanjutnya 19,9\% tercatat sebagai pengangguran dan lainnya. Pada usia-usia tersebut, kebanyakan remaja masih dalam proses menempuh dunia pendidikan, yaitu sekitar 58,6\% atau 14.119.947. Rendahnya jumlah data remaja yang bekerja antara usia 15-19 tahun menjadi salah satu alasan bahwa perkawinan usia muda (19 dan 16 tahun) belum memiliki kesiapan yang matang, terlebih bagi seorang suami. ${ }^{54}$

3) Aplikasi Kaidah Fiqhiyyah terhadap Batas Usia Perkawinan dalam Undang-Undang Perkawinan

\footnotetext{
${ }^{52}$ Agoes Dariyo, Psikologi Perkembangan Dewasa Muda, (Jakarta : Grasindo, 2004), hlm. 62

${ }^{53}$ Andi Mappiare, Psikologi Orang Dewasa, hlm. 19.

${ }^{54}$ https://www.bps.go.id/statictable/2016/04/04/1904/penduduk-berumur-15-tahun-ke-atas-menurutgolongan-umur-dan-jenis-kegiatan-2008---2017.html
} 
Moh Luthfi Hakim

Di samping perkawinan usia remaja belum dianggap dewasa dalam kajian ilmu psikologi perkembangan, pada umumnya perkawinan tersebut akan menimbulkan dampak negatif terutama pada perempuan. Perempuan pada usia remaja belum memiliki alat reproduksi yang sempurna. Perempuan hamil dan melahirkan di bawah usia 20 tahun (premature pregnancy) akan berdampak pada 2-5 kali lebih tinggi angka kematian maternal daripada perempuan hamil dan melahirkan di atas 20-29 tahun. ${ }^{55}$ Penyebab kematian maternal juga tidak terlepas dari kondisi ibu dan merupakan salah satu dari kriteria 4 "terlalu", yaitu terlalu tua pada saat melahirkan yaitu di atas 35 tahun, terlalu muda saat melahirkan yaitu dibawah 20 tahun, terlalu sering yaitu jarak persalinan terakhir dengan awal kehamilan kurang dari 2 tahun, dan terlalu banyak anak (jumlah melebihi 4 anak). ${ }^{56}$

Menurut data dari Survei Demografi dan Kesehatan Indonesia (SDKI), jumlah kematian ibu di Indonesia menunjukkan angka yang signifikan, yaitu sebanyak 390 kematian per 100.000 kelahiran. Salah satu penyebabnya adalah kurangnya akses untuk mendapatkan pengetahuan tentang kesehatan kehamilan, terutama didominasi oleh kelompok remaja dan dewasa muda. ${ }^{57}$ WHO (organisasi kesehatan internasional PBB) juga melansir kira-kira angka kematian Ibu setiap hari di seluruh dunia mencapai 830 korban, yang terhaji akibat komplikasi kehamilan, pendarahan, pernikahan dini, dan aborsi. $^{58}$

Kehamilan pada usia remaja juga berdampak pada kesehatan dan keselamatan bayi saat persalinan. Resiko kematian bayi meningkat menjadi lebih tinggi. Disamping alat reproduksinya belum sempurna, perkawinan usia remaja umumnya tidak mendapatkan informasi tentang reproduksi sebagai persiapan pra nikah yang penting untuk diketahui. ${ }^{59}$

Munculnya dampak-dampak negatif akibat terlalu rendahnya batas usia dalam pasal 7 ayat (1) Undang-Undang Perkawinan, maka penetapan usia perkawian di Indonesia

${ }^{55}$ Suryati Romauli dan Anna Vida Vindari, Kesebatan Reproduksi, (Yogyakarta: Nuha Medika, 2009), hlm. 110111.

${ }^{56}$ Intan Kumalasari dan Iwan Andhyantoro, Kesehatan Reproduksi, (Jakarta: Salemba Medika, 2012), hlm. 9.

${ }^{57}$ http://www.depkes.go.id/resources/download/pusdatin/infodatin/infodatin-ibu.pdf diakses pada tanggal 2 Maret.

${ }^{58}$ http://www.who.int/mediacentre/factsheets/fs348/en/ diakses pada tanggal 27 Maret.

${ }^{59}$ Intan Kumalasari dan Iwan Andhyantoro, Kesehatan Reproduksi, hlm. 21. 
harus mempertimbangkan kesesuaian dengan definisi kedewasaan baik secara fisik maupun psikis. Penambahan batas usia perkawinan sampai seorang dianggap dewasa tidak dimaksudkan menghambat perkawinan, namun bertujuan untuk kemaslahatan umum serta sebagai upaya preventif dari dampak-dampak buruk akibat perkawinan usia muda. Ini sejalan dengan kaidah fiqh yang disebutkan oleh Imam Suyuthi dalam kitabnya: ${ }^{60}$

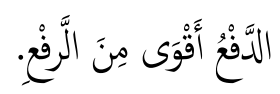

Artinya: Mencegah lebih utama daripada menghilangkan.

Dalam kitab al-Ashbāh wa an-Nadäir imam Suyuthi menjelaskan bahwa mencegah kemungkinan terjadinya mudarat (preventif) lebih baik daripada menghilangkan mudarat. Aplikasi kaidah ini dapat pula diperluas pada persoalan pembatasan usia perkawinan dalam Undang-Undang Perkawinan. Artinya bahwa mencegah lahirnya dampak-dampak negatif akibat perkawinan usia muda akan sangat lebih utama dibanding mencari solusi atas problem rumah tangga yang akan muncul. Oleh karenanya batas usia perkawinan sudah sepatutnya disesuaikan dengan kondisi Indonesia saat ini. selain bertujuan menghindari madarat, penambahan batas usia perkawinan juga bermuara untuk mendatangkan kemaslahatan umum.

c. Batas Usia Perkawinan dalam Undang-Undang Perkawinan Perspektif Madzhab Manhaji Fiqh Sosial (Pengembangan Teori Masälikul Illat)

Dalam konteks pembatasan usia kawin, baligh sebagai syarat calon mempelai sepatutnya dilihat sebagai jalan untuk mewujudkan tujuan utama berumah tangga. Sementara pada saat ini jika definisi baligh dalam fiqh dipandang tidak sesuai dengan tujuan perkawinan, maka usaha penetapan usia perkawinan dalam bentuk angka menjadi keniscayaan. Sekilas terlihat bertentangan, tetapi pada hakikatnya memiliki tujuan yang sama, meskipun sarana (wasilah) untuk sampai pada tujuan tersebut adalah berbeda.

Penerapan metode bermadzhab secara manhaji fiqh sosial dalam melihat persoalan pembatasan usia kawin dilakukan dengan cara mengintegrasikan 'illat (legal of reason)

${ }^{60}$ Jalaluddin Abdurrahaman as-Suyuthi, al-Ashbāh wa an-Nad̄äir, (Riyadh: Maktabah Nizar, 1997) h. 229 
Moh Luthfi Hakim

diperintahkannya perkawinan dengan hikmah hukumnya (tujuan yang hendak dicapai). Perintah perkawinan dapat dijumpai dalam hadist yang berbunyi:

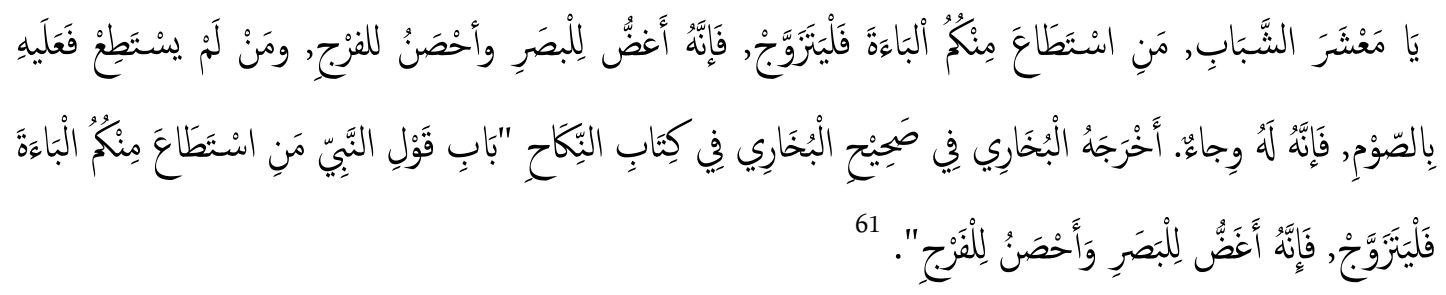

Artinya: wahai para pemuda, barangsiapa diantara kamu yang sudah mampu menikah, maka menikablah, sesunggubnya ia lebih menjaga pandangan dan memelihara kemaluan, dan barangsiapa tidak mampu, hendaklah berpuasa, sesunggubnya ia sebagai perisai baginya.

Menurut sebagian ulama arti kata al-bäah adalah kemampuan bersetubuh. Sementara pendapat lain mengatakan makna yang tepat adalah adalah kemampuan menikah (biaya menikah). Selain dua pendapat ini, ada juga ulama fiqh yang menambahkan bahwa al-bäah mengandung arti baligh dan mempunyai kemampuan menikah. ${ }^{62}$

Hadis di atas sudah sangat jelas bahwa illat atas perintah menikah adalah al-bäab (kemampuan bersetubuh). Illat $a l-b a ̈ a h$ inilah yang menjadi salah satu syarat bagi calon mempelai atas adanya perintah perkawinan. Menurut pengembangan teori masälikul 'illah fiqh sosial, illat hukum tersebut tidak boleh berdiri sendiri, tetapi harus terintegrasi dengan hikmah serta tujuan perkawinan supaya kemaslahatan dapat diwujudkan, baik kemaslahatan berdimensi personal maupun sosial. Paradigma seperti inilah yang oleh Kiai Sahal disebut dengan "integrasi hikmah hukum ke dalam illat hukum” agar hukum yang dihasilkan membawa kemaslahatan bagi semua pihak. ${ }^{63}$

Kemaslahatan sendiri memang sulit diukur termasuk kemaslahatan yang berhubungan dengan pembatasan usia kawin, sebab kemaslahatan merupakan suatu nilai yang tidak tampak secara fisik, sehingga kemaslahatan tidak dapat menjadi illat hukum. Arti maslahah menurut Imam Ghazali yaitu menjaga lima tujuan syari'. Pemenuhan atas lima tujuan syariah itulah yang menjadi indikasi terwujudnya

${ }^{61}$ Imam al-Bukhari, Șahịh al-Bukhäry, hadis nomor 5066, hlm. 1293.

${ }^{62}$ Ibnu Hajar al-'Asqalany, Fathu al-Bārī, juz 11, (Riyadh: Dar Thayyibah, 2005), hlm. 331- 322

${ }^{63} \mathrm{MA}$. Sahal Mahfudh, Nuansa Figh Sosial, hlm. IIV. 
kemaslahatan. ${ }^{64}$ Sementara Kiai Sahal mendefinisikan kemaslahatan umum sebagai kebutuhan nyata masyarakat dalam suatu kawasan tertentu untuk menunjang kesejahteraan lahiriahnya. Baik kebutuhan tersebut bersifat kebutuhan dasar (basic need) yang menjadi sarana pokok untuk mencapai keselamatan agama, jiwa, akal, nasab dan harta, maupun kebutuhan sekunder dan kebutuhan yang bersifat pelengkap. ${ }^{65}$

Dalam kerangka pandang ini, maka semua aspek kehidupan yang melingkupi kehidupan manusia kecuali yang bersifat ibadah murni, harus disikapi dengan meletakkan kemanfaatan dan kemaslahatan sebagai bahan pertimbangan penetapan hukum. Termasuk dengan Undang-Undang Perkawinan dalam menentukan batas usia perkawinan, dimana ia harus dilihat dari berbagai sudut pandang dan bermuara pada tercapainya tujuan perkawinan serta kemaslahatan yang berdimensi sosial (al-mașlahah al-'ámmah).

Hal ini sesuai dengan apa yang disampaikan oleh Imam Suyuthi dalam kaidah fiqh berbunyi:

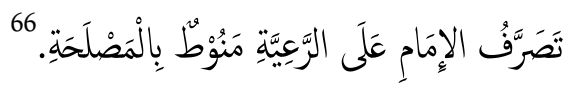

Kebijakan pemimpin atau negara harus berorientasi pada kemaslabatan rakyatnya.

Di antara al-mașlahah al-ämmah yang dapat diwujudkan ketika seseorang menikah pada usia dewasa dan matang (sebagai refleksi dari makna al-bäab) adalah sebagai berikut:

1) Pembatasan usia perkawinan sebagai sarana menciptakan keluarga ideal dan melahirkan generasi berkualitas.

Usaha menciptakan keluarga berkualitas harus diperhatikan dalam kehidupan berumah tangga, sebab ia secara tidak langsung akan membangun kondisi masyarakat Indonesia, dan sebaliknya kualitas keluarga yang rendah akan berdampak pada rendahnya kualitas masyarakat Indonesia secara luas. Dalam merealisasikan keluarga ideal tentunya prasarana dan sarana menuju hal itu juga harus dipenuhi. Karena rumah tangga tidak hanya berlangsung dalam jangka waktu pendek, tetapi

${ }^{64}$ Al-Ghazaly, al-Mustașfā, (Beirut: Dar Kutub al-Ilmiah, 1993), hlm. 139-140.

${ }^{65} \mathrm{MA}$. Sahal Mahfudh, Nuansa Figh Sosial, hlm. 9.

${ }^{66}$ Jalaluddin Abdurrahaman as-Suyuthy, al-Ashbāh wa an-Nadäir, hlm. 202. 
Moh Luthfi Hakim

selamanya dan saling berkesinambungan, yang bertugas melahirkan generasi manusia berpendidikan baik, sehat jasmani dan rahani, dan mempunyai kesejahteraan dalam bidang ekonomi di masa mendatang sehingga penetapan batas minimal usia kawin bagi calon mempelai harus sesuai dengan cita-cita masyarakat.

Peran pembatasan usia kawin (dewasa) sangat penting bagi terciptanya keluarga ideal dan lahirnya generasi-generasi unggul. Pentingnya membentuk keluarga ideal dan melahirkan generasi unggul didasarkan atas dalil naqli sebagaimana firman Allah dalam surat an-Nisa' (4) ayat 9:

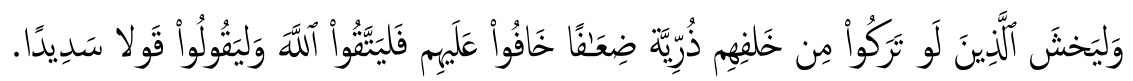

Artinya: "Dan hendaklah takut kepada Allah orang-orang yang seandainya meninggalkan dibelakang mereka anak-anak yang lemah, yang mereka khawatir terhadap (kesejabteraan) mereka. Oleh sebab itu hendaklah mereka bertakwa kepada Allah dan hendaklah mereka mengucapkan perkataan yang benar.”

Selain ayat di atas, urgensi menciptakan keluarga yang berkualitas juga terangkum dalam hadits Rasulullah yang berbunyi:

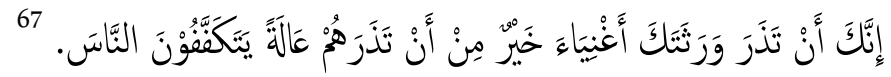

Sesunggubnya lebih baik bagimu meninggalkan abli warismu dalam keadaan berkecukupan dari pada meninggalkannya menjadi beban bagi orang banyak (meminta-minta).

Konsep Keluarga berkualitas memang sulit untuk dirumuskan secara pasti dan berlaku bagi setiap keluarga. Akan tetapi kemaslahatan dan kesejahteraan sebuah keluarga pada prinsipnya bermuara pada pemenuhan kebutuhan keluarga. ${ }^{68}$ Penetapan usia perkawinan di Indonesia sampai calon mempelai tergolong usia dewasa jelas akan menyasar pada 3 aspek penting dalam keluarga, yaitu peningkatan kualitas sumber daya manusia, terjaganya kesehatan ibu dan anak, sekaligus terpenuhinya pendidikan anak. ${ }^{69}$

\footnotetext{
${ }^{67}$ Imam al-Bukhari, Sahịh al-Bukhäriy, hadis nomor 4409, hlm.1079.

${ }^{68} \mathrm{MA}$. Sahal Mahfudh, Nuansa Fiqh Sosial, hlm. 10

${ }^{69}$ Cholil Nafis, Abdullah Ubaid, Keluarga Maslabah Terapan Fikib Sosial Kyai Sabal, (Jakarta: Mitra Abadi Press, 2010), hlm. 119.
} 
Perkawinan di usia 19 dan 16 tahun dikhawatirkan berdampak pada ketidakmampuan orangtua untuk memenuhi berbagai macam hak anaknya, misalnya hak atas akses pendidikan dan kesehatan. Hal tersebut dikarenakan orang tua yang menikah muda (terlebih suami) belum memiliki kemampuan finansial yang cukup untuk memenuhi berbagai kebutuhan yang diperlukan dalam rumah tangga. Tentu saja hal ini akan berpengaruh pada tingginya angka anak putus sekolah di Indonesia. Berdasarkan ikhtisar data pendidikan, tercatat pada tahun 2016/2017 anak putus sekolah pada tingkat SMP sebanyak 38.702, tingkat SMA sejumlah 36.419 dan tingkat SMK adalah 72.744. Dari sedemikian banyak data anak putus sekolah di Indonesia, faktor ekonomi orang tua menjadi penyebab utama terhadap persoalan ini. $^{70}$

2) Pembatasan usia perkawinan menjadi solusi atas pertumbuhan penduduk Indonesia yang tidak seimbang.

Total jumlah penduduk Indonesia pada tahun 2010 sudah mencapai lebih dari 230 juta jiwa, diprediksi pada tahun 2025 penduduk Indonesia akan mencapai 263 juta jiwa. Statistik ini menunjukkan laju pertumbuhan penduduk Indonesia dapat dikatakan diatas ambang normal, atau biasa disebut ledakan penduduk. Boleh jadi jumlah penduduk yang besar memang merupakan potensi yang besar dan sebuah kebanggaan. Akan tetapi juga harus disadari bahwa hanya dengan kuantitas penduduk yang besar tidak akan menjamin peningkatan kualitas apapun. Jika hal tersebut tidak dikendalikan dari sekarang, selanjutnya akan menambah permasalahan yang sudah ada, seperti: penyediaan lapangan kerja, pengangguran, kemiskinan dan kerusakan lingkungan. ${ }^{71}$

Pembatasan usia perkawinan dalam Undang-Undang Perkawinan mempunyai peran signifikan terhadap lonjakan penduduk di Indonesia. Semakin muda seseorang menikah akan semakin cepat mempunyai keturunan. Di Indonesia usia 19 dan 16 tahun belum masuk dalam kategori SDM yang mumpuni dalam hal ekonomi untuk

\footnotetext{
${ }^{70} \mathrm{http}: / /$ publikasi.data.kemdikbud.go.id/uploadDir/isi_FC1DCA36-A9D8-4688-8E5F0FB5ED1DE869_.pdf

${ }^{71}$ http://sp2010.bps.go.id/ Perhitungan berdasarkan data Badan Pusat Statistik dengan memperkirakan bahwa laju pertumbuhan penduduk sama dengan pertumbuhan 10 tahun lalu, dimana rasio kelahiran sebesar 1,5 persen.
} 
Moh Luthfi Hakim

menjamin kesehatan keluarga, membesarkan dan memberikan akses pendidikan terhadap anak-anak, dan demikian seterusnya. Mata rantai inilah yang menyebabkan adanya ketidakseimbangan antara pertumbuhan penduduk dengan Sumber Daya Manusia.

C.A. Sanchez mengutip pendapat Thomas Malthus telah meramalkan bahwa ledakan penduduk yang tidak terkontrol akan menyebabkan masalah, terutama kesediaan pangan. Pertumbuhan jumlah penduduk yang meningkat bila tidak dikendalikan akan naik menurut deret ukur (1,2,4,8, dan seterusnya). Sementara disisi lain produksi pangan hanya meningkat menurut deret hitung. Ledakan penduduk dunia pada saat ini mengakibatkan dampak sosial berupa krisis pangan secara global, termasuk Indonesia. ${ }^{72}$ Di dalam aspek ekonomi, masalah yang timbul dari laju kependudukan ditandai dengan meningkatnya jumlah orang miskin, jumlah pengangguran, dan pendapatan (income) masyarakat yang rendah. Kepadatan penduduk mengakibatkan berbagai kesulitan ekonomi. Kian menyempitnya lapangan kerja akan berdampak pada minimnya kesempatan kerja serta meningkatnya pengangguran. Tidak sampai di sana, laju pertumbuhan penduduk yang tidak seimbang dengan pertumbuhan ekonomi bisa merembet pada masalah sosial maupun kriminal.

Hampir semua aspek dan faktor kehidupan berkaitan erat dan saling mempengaruhi dengan masalah kependudukan, seperti tingginya laju perkembangan penduduk, persebarannya tidak merata, dan struktur umur penduduk yang relatif muda, semua berkaitan erat dengan aspek kependudukan yang cenderung menimbulkan kerawanan sosial serta ketimpangan sektor pendidikan, kesehatan, ekonomi, ketenagakerjaan, keamanan, dan keagamaan. Bahkan dari masalah kependudukan ini kita bisa menelusuri munculnya kemiskinan struktural, krisis lingkungan, dan lain-lain. ${ }^{73}$

Struktur umur penduduk yang muda merupakan implikasi dari adanya praktik perkawinan usia muda. Pada kenyataannya memang tanggung jawab yang dipikul

${ }^{72}$ C.A. Sanchez, Pendidikan Kependudukan (Jakarta: Penerbit Bumi Aksara, 1985) hlm. 143.

${ }^{73}$ MA. Sahal Mahfudh, Nuansa Figh Sosial, hlm. 6 
oleh lelaki sebagai suami serta ayah bagi anaknya, dan tanggung jawab yang dipikul oleh wanita sebagai istri serta ibu bagi anaknya untuk memenuhi kebutuhan dalam rumah tangga tidak semakin ringan. Tuntutan masa sekarang berbeda dengan kondisi masa lalu, di mana kehidupan sosial masih sederhana dan kebutuhan keluarga belum beragam. Dalam kondisi yang demikian maka semakin muda pasangan suami istri akan semakin berat memikul tanggung jawab tersebut. Padahal tanggung jawab di sini bukan sekedar tanggung jawab di dunia, tetapi juga tanggung jawab di akhirat nanti.

\section{E. Penutup}

Berdasarkan penjelasan tersebut sangat jelas bahwa "usia yang belum dewasa" menjadi akar utama dari permasalahan perkawinan usia muda dalam kaitannya dengan upaya mencapai tujuan perkawinan. Selain itu juga menjadi penyebab terhadap lahirnya dampak buruk pada perkawinan muda. Dalam konteks ini, pembatasan usia perkawinan yang diberikan oleh Undang-Undang belum sesuai dengan aspek pemenuhan kebutuhan psikologis dan biologis dimana kebutuhan-kebutuhan tersebut wajib terpenuhi dalam perkawinan.

Berdasarkan aplikasi madzhab qauli Fiqh Sosial, bäligh sebagai salah satu syarat calon pengantin dalam literatur fiqh harus dipahami secara kontekstual. Secara umum pada dasarnya upaya Undang-Undang Perkawinan dalam menetapkan usia 19 dan 16 tahun pada tahun 1974 sebagai batas usia perkawinan telah masuk dalam kategori kontekstualisasi terhadap kitab kuning, akan tetapi konteks Indonesia pada tahun 1974 sudah sangat berbeda dengan kondisi saat ini, sehingga pembatasan usia perkawinan tersebut dinilai terlalu rendah. Akibatnya akan melahirkan dampak-dampak negatif. Maka upaya preventif terhadap lahirnya dampak-dampak negatif harus dilakukan, sesuai dengan kaidah fiqh ad-daf'u aqwā min ar-rafi

Sementara itu, madzhab manhaji fiqh sosial memandang bahwa íllat perintah atas perkawinan (al-bäah) perlu terintegrasi dengan upaya untuk mewujudkan kemaslahatan umum (al-mașlahah al-'ámmah). Sebagai interpretasi dari makna al-bä’ah, pembatasan usia perkawinan dalam Undang-Undang harus terintegrasi dengan upaya untuk mewujudkan 
Moh Luthfi Hakim

tujuan perkawinan serta menciptakan kemaslahatan. Diantara kemaslahatan yang akan terwujud ketika seseorang menikah pada usia dewasa adalah dapat menjadi sarana menciptakan keluarga ideal dan melahirkan generasi yang berkualitas, serta dapat menjadi salah satu solusi terhadap persoalan lonjakan jumlah penduduk di Indonesia, sebab ketidakseimbangan lonjakan penduduk ini akan berimplikasi pada masalah pendidikan anak, kesehatan keluarga, sampai ketersediaan lapangan kerja.

\section{Daftar Pustaka}

‘Asqalany, Al, Ibnu Hajar, 2005. Fathu al-Bārì, Riyadh: Dar Thayyibah.

Abdullah, 1997. Al-Mughny, Riyadh: Dar Alam Al-kutub.

Amiruddin dan Asikin, Zainal, 2006. Pengantar Metode Penelitian Hukum, Jakarta: Rajawali Pers.

Arikunto, Suharsimi, 2006. Prosedur Penelitian: Suatu Pendekatan Praktik, Jakarta: Rineka Cipta.

Baroroh, Umdatul dan Janah, Tutik Nurul, 2016. Fiqh Sosial: Masa Depan Fiqh Indonesia, Pati: PUSAT FISI Institut Pesantren Mathali'ul Falah.

Bukhari, Al, 2002 Șaḥịh al-Bukhäry, Beirut: Dar Ibn Katsir.

Daradjat, Zakiah, 1995. Remaja: Harapan dan Tantangan, Jakarta: Ruhama.

Dariyo, Agoes, 2004. Psikologi Perkembangan Dewasa Muda, Jakarta: Grasindo.

Ghazaly, Al, al-Mustaşfä, 1993. Beirut: Dar Kutub al-Ilmiah.

Ghazy, Al, Muhammad, Fath al-Qarib al-Mujizb, Jakarta: Dar al-Kutub al-Islamiyah.

Halim, Abdul, 2008. Politik Hukum Islam di Indonesia, Jakarta: Badan Litbang dan Diklat Departemen Agama RI.

Jawi, Nawawi al, Muhammad bin Umar, 2002. Nihāyāt az-Zain, Beirut: Dar al-Kutub alIlmiyah.

Kaharuddin, 2015. Nilai-Nilai Filosofi Perkawinan, Jakarta: Mitra Wacana Media.

Kartono, Kartini, 1995. Psikologi Anak (Psikologi Perkembangan), Bandung : Mandar Maju.

Kumalasari, Intan dan Andhyantoro, 2012. Iwan, Kesehatan Reproduksi, Jakarta: Salemba Medika.

Mahfudh, MA. Sahal, 2011. Nuansa Figh Sosial, Cet. VII, Yogyakarta: LkiS.

2014. Mengaktualkan Fiqh Klasik di Era Global dalam Epistemologi Fiqh Sosial, Pati: Fiqh Sosial Institute. 
1999. Pesantren Mencari Makna, Jakarta: Pustaka Ciganjur.

Mappiare, Andi, 1983. Psikologi Orang Dewasa, Surabaya: Usaha Nasional.

Marzuki, Peter Mahmud, 2007. Penelitian Hukum, Jakarta: Kencana.

Muhammad, Abdul Kadir, 2004. Hukum dan Penelitian Hukum, Bandung: PT. Citra Aditya Bakti.

Nafis, Cholil, dan Ubaid, Abdullah, 2010. Keluarga Maslahah Terapan Fikih Sosial Kyai Sabal, Jakarta: Mitra Abadi Press.

Qurtuby, Al, Muhammad, al-jāmi' Li Abkàm al-Qur'ān, Beirut: ar-Risalah.

Qurtuby, Sumanto Al, 2017. KH. MA. Sahal Mahfudh: Era Baru Fiqh Pesantren, Semarang: Elsa PresS.

Romauli, Suryati dan Vindari, Anna Vida, 2009. Kesehatan Reproduksi, Yogyakarta: Nuha Medika.

Sanchez, C.A., 1985. Pendidikan Kependudukan Jakarta: Penerbit Bumi Aksara.

Santrock, John W., Remaja, 2007. terjemah oleh penerbit Erlangga, Jakarta: Erlangga.

Shihab, M. Quraish, 2007. Pengantin Al-Qur'an, Jakarta: Lentera Hati.

Summa, Muhammad Amin, 2004. Hukum Keluarga Islam di Dunia Islam, Jakarta: Raja Grafindo Persada.

Suyuthi, As, Jalaluddin Abdurrahaman, 1997. Al-Ashbāh wa An-Nadäir, Riyadh: Maktabah Nizar.

Wahid, Marzuki, 2014. Figh Indonesia: Kompilasi Hukum Islam dan Counter Legal Draft Kompilasi Hukum Islam dalam Bingkai Politik Hukum Indonesia, Bandung: Marja. 